\title{
Planotetraspora kaengkrachanensis sp. nov. and Planotetraspora phitsanulokensis sp. nov., isolated from soil
}

Correspondence

Vichien Kitpreechavanich

fsciwck@ku.ac.th

\author{
Chanwit Suriyachadkun, ${ }^{1,2}$ Suwanee Chunhametha, ${ }^{2}$ Chitti Thawai, ${ }^{3}$ \\ Tomohiko Tamura, ${ }^{4}$ Wanchern Potacharoen, ${ }^{2}$ Kanyawim Kirtikara, ${ }^{2}$ \\ Jean-Jacques Sanglier ${ }^{2,5}$ and Vichien Kitpreechavanich ${ }^{1}$ \\ ${ }^{1}$ Faculty of Science, Kasetsart University, Bangkok 10900, Thailand \\ ${ }^{2}$ Bioresources Technology Unit, National Center for Genetic Engineering and Biotechnology, \\ National Science and Technology Development Agency, 113 Thailand Science Park, \\ Phaholyothin Road, Klong 1, Klong Luang, Pathumthani 12120, Thailand \\ ${ }^{3}$ Department of Applied Biology, Faculty of Science, King Mongkut's Institute of Technology \\ Ladkrabang, Bangkok 10520, Thailand \\ ${ }^{4}$ Biological Resource Center, National Institute of Technology and Evaluation, 2-5-8 \\ Kazusakamatari, Kisarazu, Chiba 292-0812, Japan \\ ${ }^{5}$ Novartis Institutes for BioMedical Research Basel, Natural Products Unit, Novartis Pharma AG, \\ Basel, Switzerland
}

Two novel bacterial strains were isolated from tropical rain forest soil from Thailand. Strains A-T $0875^{\top}$ and A-T $1383^{\top}$ stained Gram-positive and were filamentous bacteria that developed cylindrical sporangia containing four oval- to rod-shaped spores at the ends of short sporangiophores on branched aerial mycelium. The cell-wall peptidoglycan contained mesodiaminopimelic acid, glutamic acid and alanine as cell-wall amino acids; whole-cell hydrolysates contained rhamnose, madurose, glucose, galactose and 3-O-methylmannose as whole-cell sugars. The predominant menaquinone was MK- $9\left(\mathrm{H}_{4}\right)$. Mycolic acids were not detected. The diagnostic phospholipid was phosphatidylethanolamine. The predominant cellular fatty acids were iso- $\mathrm{C}_{16: 0}$ and 10-methyl- $\mathrm{C}_{17: 0}$. For both strains, the $\mathrm{G}+\mathrm{C}$ content of the genomic DNA was $71 \mathrm{~mol} \%$. Phenotypic and chemotaxonomic analyses showed that the characteristics of the two isolates were typical of members of the genus Planotetraspora. Furthermore, 16S rRNA gene sequence analysis also indicated that the strains belonged to the genus Planotetraspora but as representatives of two novel species. Following an evaluation of our phenotypic, chemotaxonomic and genotypic studies, two novel species are proposed, Planotetraspora kaengkrachanensis sp. nov. (type strain A-T $0875^{\top}=\mathrm{BCC} 24832^{\top}=\mathrm{NBRC} 104272^{\top}$ ) and Planotetraspora phitsanulokensis sp. nov. (type strain A-T $1383^{\top}=B C C 26045^{\top}=\mathrm{NBRC}_{104273^{\top}}$ ).
The genus Planotetraspora was first proposed by Runmao et al. (1993) and classified in the family Streptosporangiaceae and, at the time of writing, it included three recognized species: Planotetraspora mira (Runmao et al., 1993) as the type species, Planotetraspora silvatica (Tamura \& Sakane, 2004) and Planotetraspora thailandica (Suriyachadkun et al., 2009). Members of the genus are Gram-positive, nonacid-fast and aerobic. They develop cylindrical sporangia

Abbreviation: meso- $\mathrm{A}_{2} \mathrm{pm}$, meso-diaminopimelic acid.

The GenBank/EMBL/DDBJ accession numbers for the 16S rRNA gene sequences of Planotetraspora kaengkrachanensis A-T $0875^{\top}$ and Planotetraspora phitsanulokensis A-T $1383^{\top}$ are FJ426333 and FJ426332, respectively. containing four non-motile spores at the ends of short sporangiophores on the aerial mycelium. Substrate mycelium is non-fragmented. Vegetative mycelia are white to pale yellow and good growth is observed between 25 and $30{ }^{\circ} \mathrm{C}$. These strains have meso-diaminopimelic acid (meso$\mathrm{A}_{2} \mathrm{pm}$ ), glutamic acid and alanine in the cell wall. They contain madurose and rhamnose as whole-cell sugars. Mycolic acids are not detected. MK- $9\left(\mathrm{H}_{4}\right)$ is the major isoprenoid quinone and the phospholipid pattern is type PIV. The predominant cellular fatty acids are iso- $\mathrm{C}_{16: 0}$ and 10-methyl- $\mathrm{C}_{17: 0}$ corresponding to fatty acid pattern $3 \mathrm{c}$ of Kroppenstedt (1985). The DNA G+C content is 70$71 \mathrm{~mol} \%$. The genus Planotetraspora is closely related to the genera Microbispora (Nonomura \& Ohara, 1957), 
Microtetraspora (Thiemann et al., 1968), Herbidospora (Kudo et al., 1993) and Acrocarpospora (Tamura et al., 2000). Members of these genera exhibit a high 16S rRNA gene sequence similarity, but members of the genus Planotetraspora can be distinguished from those of the other four genera on the basis of morphological and chemotaxonomic criteria.

During a project on the diversity of actinomycetes in Thailand, strains A-T $0875^{\mathrm{T}}$ and A-T $1383^{\mathrm{T}}$ were isolated from forest soils collected from Kaeng Krachan District in Prachuap Khiri Khan Province and Nakhon Thai District in Phitsanulok Province, respectively. The isolates were identified as two novel members of the genus Planotetraspora based on morphological and chemotaxonomic studies, phylogenetic analysis and DNA-DNA relatedness studies. Therefore, we consider that A-T $0875^{\mathrm{T}}$ and A-T $1383^{\mathrm{T}}$ represent two novel species, Planotetraspora kaengkrachanensis sp. nov. and Planotetraspora phitsanulokensis sp. nov., respectively.

Strain A-T $0875^{\mathrm{T}}$ was isolated from soil samples treated with phenol as recommended by Hayakawa et al. (1991) and strain A-T $1383^{\mathrm{T}}$ was isolated from soil samples that were thermally treated $\left(100{ }^{\circ} \mathrm{C}\right.$ for $\left.1 \mathrm{~h}\right)$. The strains were isolated on humic acid salts-vitamin (HV) agar supplemented with $25 \mathrm{mg}$ nalidixic acid $\mathrm{l}^{-1}, 50 \mathrm{mg}$ cycloheximide $1^{-1}$ and $1 \mathrm{mg}$ terbinafine $\mathrm{l}^{-1}$. Pure cultures were preserved by freezing at $-80{ }^{\circ} \mathrm{C}$ in glycerol $(15 \%, \mathrm{v} / \mathrm{v})$ and liquid-drying.

For determination of morphological characteristics, growth on modified soil extract agar, yeast extract-starch agar (Suriyachadkun et al., 2009) and inorganic salts-starch agar (ISP4 medium; Shirling \& Gottlieb, 1966) for 7-14 days at $28{ }^{\circ} \mathrm{C}$ was observed with a light microscope and a scanning electron microscope (model JSM-5410 LV; JEOL). Samples grown on modified soil extract agar for scanning electron microscopy were prepared as described previously (Itoh et al., 1989).

Characteristics of strains A-T $0875^{\mathrm{T}}$ and A-T $1383^{\mathrm{T}}$ were typical of those of members of the genus Planotetraspora. They developed cylindrical sporangia $(0.8-1.0 \times 2.0$ $3.0 \mu \mathrm{m})$ containing four oval- to short rod-shaped spores $(0.4-0.6 \times 0.8-1.0 \mu \mathrm{m})$ at the ends of short sporangiophores on the aerial mycelium. The spores were not motile, as determined by light microscopy of cells grown on HV agar for 10 days at $28{ }^{\circ} \mathrm{C}$ and then incubated at $28{ }^{\circ} \mathrm{C}$ for 30-60 min in 0.1 M potassium phosphate buffer ( $\mathrm{pH}$ 7).

The phenotypic characteristics of the two novel strains were examined by using several standard methods. Cultural characteristics were tested using 14-21 day cultures grown at $28{ }^{\circ} \mathrm{C}$ on various agar media (Shirling \& Gottlieb, 1966). The NBS-ISCC colour system was used to determine the names and designations of colony colours. The temperature, $\mathrm{pH}$ and $\mathrm{NaCl}$ tolerance for growth were determined on ISP2 medium. Acid production from carbon sources was examined using the medium recommended by Gordon et al. (1974). Utilization of carbohydrates as sole carbon sources was tested by using ISP9 medium as a basal medium (Shirling \& Gottlieb, 1966) supplemented with a final concentration of $1 \%$ carbon source. Gelatin liquefaction, peptonization of milk, nitrate reduction and starch hydrolysis were determined by cultivation on various media as described by Arai (1975) and Williams \& Cross (1971). The results are indicated in detail in the species description and Table 1.

Freeze-dried cells used for chemotaxonomic analyses were obtained from a culture grown in glucose-yeast extract broth (Tamura et al., 1994) on a rotary shaker at $30{ }^{\circ} \mathrm{C}$ for 7 days. Cell-wall peptidoglycan was prepared and hydrolysed according to the methods of Kawamoto et al. (1981) and the amino acid composition was determined by HPLC. The $\mathrm{A}_{2} \mathrm{pm}$ isomer in the cell wall was determined by using the method of Staneck \& Roberts (1974). The acyl group of the muramic acid in the peptidoglycan was determined by using the method of Uchida \& Aida (1984). The reducing sugars from whole-cell hydrolysates were analysed by HPLC using a Sugar-Pak column (Waters) according to Mikami \& Ishida (1983). Cell phospholipids were extracted and analysed by using the method of Minnikin et al. (1984). Fatty acid methyl ester analysis was performed by GLC according to the instructions of the Microbial Identification System (MIDI) (Sasser, 1990; Kämpfer \& Kroppenstedt, 1996). Isoprenoid quinones were extracted according to the method of Collins et al. (1977) and analysed by HPLC [Cosmosil $5 \mathrm{C}_{18}$ column $(4.6 \times 150 \mathrm{~mm})$; Nacalai Tesque] with a mixture of methanol and 2propanol $(2: 1, \mathrm{v} / \mathrm{v})$ as elution solvent.

The chemotaxonomic characteristics of the two novel strains were similar to those of members of the genus Planotetraspora. Cell-wall amino acids contained meso$\mathrm{A}_{2} \mathrm{pm}$, alanine and glutamic acid. These amino acids correspond to murein type $\mathrm{A} 1 \gamma$ as described by Schleifer \& Kandler (1972). The two novel strains contained rhamnose, madurose, glucose, galactose and 3-O-methylmannose as whole-cell sugars, but not arabinose or xylose (whole-cell sugar pattern B of Lechevalier \& Lechevalier, 1970). Phosphatidylethanolamine was detected, but phosphatidylglycerol, phosphatidylcholine and glucosamine-containing phospholipids were not detected. This pattern corresponds to phospholipid type PIV of Lechevalier et al. (1977). The cellular fatty acid compositions of strains A-T $0875^{\mathrm{T}}$ and A-T $1383^{\mathrm{T}}$ and the three recognized Planotetraspora species are shown in Table 2. Strain A-T $0875^{\mathrm{T}}$ contained iso- $\mathrm{C}_{16: 0}, 10$-methyl- $\mathrm{C}_{17: 0}$, iso- $\mathrm{C}_{15: 0}$ and $\mathrm{C}_{15: 0}$, and strain A-T $1383^{\mathrm{T}}$ contained iso- $\mathrm{C}_{16: 0}, 10-$ methyl- $\mathrm{C}_{17: 0}$, iso- $\mathrm{C}_{15: 0}$ and anteiso- $\mathrm{C}_{17: 0}$, corresponding to fatty acid pattern $3 c$ of Kroppenstedt (1985), but 10methyl- $\mathrm{C}_{18: 0}$ was not detected as a major component. Mycolic acids were absent. The major menaquinone found in the two novel strains was MK-9 $\left(\mathrm{H}_{4}\right)$.

Genomic DNA was prepared using a slight modification of the method of Saito \& Miura (1963). The 16S rRNA gene 
Table 1. Characteristics differentiating members of the genus Planotetraspora

Species: 1, P. kaengkrachanensis sp. nov. A-T $0875^{\mathrm{T}}$ (data from this study); 2, P. phitsanulokensis sp. nov. A-T 1383 ${ }^{\mathrm{T}}$ (data from this study); 3 , P. thailandica BCC $21825^{\mathrm{T}}$ (Suriyachadkun et al., 2009); 4, P. mira NBRC $15435^{\mathrm{T}}$ (Suriyachadkun et al., 2009); 5, P. silvatica NBRC 100141 ${ }^{\mathrm{T}}$ (Suriyachadkun et al., 2009). +, Positive; - , negative; \pm , weakly positive.

\begin{tabular}{|c|c|c|c|c|c|}
\hline Characteristic & 1 & 2 & 3 & 4 & 5 \\
\hline \multicolumn{6}{|l|}{ Colony colour on ISP2 medium } \\
\hline Degree of growth & Poor & Poor & Good & Good & Good \\
\hline Aerial mycelium or spore & White & Colourless & Pale yellow & Pale yellow & White \\
\hline Substrate mycelium & Pale yellow & Colourless & Pale yellow & Pale yellow & White to colourless \\
\hline \multicolumn{6}{|c|}{ Colony colour on ISP3 medium } \\
\hline Degree of growth & Poor & Moderate & Moderate & Poor & Moderate \\
\hline Aerial mycelium or spore & Colourless & White & Colourless & Pale yellow & Yellowish white \\
\hline Substrate mycelium & Colourless & White & Colourless & Pale yellow & Yellowish white \\
\hline $\mathrm{NaCl}$ tolerance & $\leqslant 1.5 \%$ & $\leqslant 1 \%$ & $\leqslant 1 \%$ & $\leqslant 1 \%$ & $\leqslant 3 \%$ \\
\hline \multicolumn{6}{|l|}{ Acid from: } \\
\hline D-Galactose & + & - & - & + & + \\
\hline D-Lactose & - & - & - & + & - \\
\hline D-Mannitol & + & + & + & + & - \\
\hline D-Mannose & + & + & + & + & - \\
\hline Melibiose & - & - & + & - & - \\
\hline Maltose & - & + & - & - & - \\
\hline L-Rhamnose & - & - & + & + & - \\
\hline D-Xylose & - & - & + & + & + \\
\hline \multicolumn{6}{|l|}{ Utilization of: } \\
\hline D-Fructose & - & - & + & - & - \\
\hline D-Galactose & - & + & + & \pm & + \\
\hline D-Glucose & - & + & \pm & + & - \\
\hline D-Mannitol & + & + & + & + & - \\
\hline Melibiose & \pm & - & + & \pm & + \\
\hline Raffinose & - & - & + & - & + \\
\hline L-Rhamnose & \pm & - & + & \pm & \pm \\
\hline D-Xylose & - & - & + & + & - \\
\hline Salicin & - & - & + & - & - \\
\hline Skim milk peptonization & - & - & - & - & + \\
\hline Skim milk coagulation & - & + & - & + & - \\
\hline
\end{tabular}

was amplified by PCR as described previously (Yamada et al., 2000; Katsura et al., 2001; Kawasaki et al., 1993). Two primers, 20F and 1500R (Suriyachadkun et al., 2009), were used for preliminary phylogenetic analysis. Positions in the rRNA gene fragments were based on the Escherichia coli numbering system (accession number V00348; Brosius et al., 1981). Amplified 16S rRNA genes were sequenced directly with an ABI PRISM BigDye Terminator Cycle Sequencing Ready Reaction kit on an ABI PRISM model 310 Genetic Analyzer (both from Applied Biosystems). The following primers were used for sequencing: $20 \mathrm{~F}, 520 \mathrm{~F}$, 920F, 520R, 920R and 1500R (Yukphan et al., 2004). Multiple alignments of the sequences were carried out with the software BioEdit Sequence Alignment Editor (version 7.0.0). Distance matrices for the aligned sequences were calculated by using the two-parameter method of Kimura (1980). The neighbour-joining method was used to construct a phylogenetic tree (Saitou \& Nei, 1987). Comparison of the sequence data obtained was made on 1376 bases and the robustness for individual branches was estimated by bootstrapping with 1000 replications (Felsenstein, 1985). Strain A-T $0875^{\mathrm{T}}$ exhibited highest 16S RNA gene sequence similarities of $98.7 \%$ to strain A-T $1383^{\mathrm{T}}$, P. thailandica BCC $21825^{\mathrm{T}}$ and P. mira NBRC $15435^{\mathrm{T}}$, and $98.1 \%$ to $P$. silvatica TT $00-51^{\mathrm{T}}$, whereas strain A-T $1383^{\mathrm{T}}$ exhibited highest $16 \mathrm{~S}$ RNA gene sequence similarities of $98.4,97.9$ and $98.2 \%$ to $P$. thailandica BCC $21825^{\mathrm{T}}$, P. mira NBRC $15435^{\mathrm{T}}$ and P. silvatica TT $00-51^{\mathrm{T}}$, respectively. A neighbour-joining tree showing the phylogenetic relationship between strain A-T $0875^{\mathrm{T}}, \mathrm{A}-\mathrm{T} 1383^{\mathrm{T}}$ and some members of the family Streptosporangiaceae revealed that these novel isolates should be classified in the genus Planotetraspora and that they were clearly separate from their closest relatives (Fig. 1).

The $\mathrm{G}+\mathrm{C}$ content of the genomic DNA was determined by the method of Tamaoka \& Komagata (1984) after treatment with P1 nuclease and alkaline phosphatase followed by HPLC using a Shimadzu LC-6AD apparatus equipped with a Cosmosil 5C $\mathrm{C}_{18}$-AR column $(4.6 \times 150 \mathrm{~mm}$; Nacalai Tesque $)$. 
Table 2. Cellular fatty acid composition of the five Planotetraspora species

Strains: 1, P. kaengkrachanensis sp. nov. A-T $0875^{\mathrm{T}}$ (data from this study); 2, P. phitsanulokensis sp. nov. A-T $1383^{\mathrm{T}}$ (data from this study); 3 , $P$. thailandica BCC $21825^{\mathrm{T}}$ (Suriyachadkun et al., 2009); 4, P. mira NBRC $15435^{\mathrm{T}}$ (Suriyachadkun et al., 2009); 5, P. silvatica NBRC 100141 ${ }^{\mathrm{T}}$ (Suriyachadkun et al., 2009). Values are percentages of total fatty acids. -, Not detected.

\begin{tabular}{|c|c|c|c|c|c|}
\hline Fatty acid & 1 & 2 & 3 & 4 & 5 \\
\hline \multicolumn{6}{|l|}{ Saturated } \\
\hline $\mathrm{C}_{13: 0}$ & $<1$ & $<1$ & $<1$ & $<1$ & $<1$ \\
\hline $\mathrm{C}_{15: 0}$ & 10.6 & 4.8 & 7.3 & 9.5 & 9.9 \\
\hline $\mathrm{C}_{16: 0}$ & 3.4 & 3.3 & 5.0 & 7.3 & 5.6 \\
\hline $\mathrm{C}_{17: 0}$ & 8.8 & 6.0 & 4.0 & 8.7 & 7.2 \\
\hline \multicolumn{6}{|c|}{ Unsaturated } \\
\hline $\mathrm{C}_{15: 1}$ & - & - & $<1$ & - & - \\
\hline $\mathrm{C}_{16: 1}$ & 1.0 & 1.2 & 2.0 & 1.8 & 2.4 \\
\hline $\mathrm{C}_{17: 1}$ & 6.0 & 3.7 & 3.0 & 4.6 & 6.3 \\
\hline $\mathrm{C}_{18: 1}$ & $<1$ & $<1$ & $<1$ & $<1$ & $<1$ \\
\hline \multicolumn{6}{|l|}{ Branched } \\
\hline $\mathrm{i}-\mathrm{C}_{16: 0}$ & 22.0 & 18.7 & 32.7 & 15.4 & 10.8 \\
\hline $\mathrm{i}-\mathrm{C}_{16: 1}$ & - & - & $<1$ & - & - \\
\hline $\mathrm{i}-\mathrm{C}_{17: 0}$ & 1.6 & 4.1 & $<1$ & 1.4 & 1.4 \\
\hline ai- $C_{17: 0}$ & 3.7 & 10.8 & 4.9 & 5.0 & 9.2 \\
\hline $\mathrm{i}-\mathrm{C}_{18: 0}$ & $<1$ & $<1$ & $<1$ & - & - \\
\hline \multicolumn{6}{|c|}{ 10-Methylated } \\
\hline$C_{16: 0}$ & 1.9 & 2.7 & 6.2 & 3.7 & 2.8 \\
\hline $\mathrm{C}_{17: 0}$ & 18.0 & 15.5 & 13.7 & 12.4 & 12.2 \\
\hline $\mathrm{C}_{18: 0}$ & $<1$ & 1.4 & $<1$ & 1.1 & $<1$ \\
\hline
\end{tabular}

DNA-DNA hybridization was carried out using the photobiotin-labelling method with microdilution wells as described by Ezaki et al. (1989). DNA-DNA relatedness (\%) was determined using the colorimetric method (Verlander, 1992). The $\mathrm{G}+\mathrm{C}$ contents of the genomic DNA from strains A-T $0875^{\mathrm{T}}$ and A-T $1383^{\mathrm{T}}$ were 71.0 and 70.9 mol\%, respectively. Strain A-T $0875^{\mathrm{T}}$ exhibited DNADNA relatedness levels of $32.06 \%(\mathrm{SD}=2.05)$ with strain A$\mathrm{T} 1383^{\mathrm{T}}, 22.71 \%(\mathrm{SD}=1.03)$ with $P$. thailandica $\mathrm{BCC}$ $21825^{\mathrm{T}}, 37.71 \%(\mathrm{SD}=1.18)$ with $P$. mira $\mathrm{NBRC} 15435^{\mathrm{T}}$ and $32.87 \%(\mathrm{SD}=0.46)$ with $P$. silvatica NBRC $100141^{\mathrm{T}}$. Strain A-T $1383^{\mathrm{T}}$ exhibited DNA-DNA relatedness levels of $17.85 \% \quad(\mathrm{SD}=1.13)$ with $P$. thailandica BCC $21825^{\mathrm{T}}$, $33.17 \% \quad(\mathrm{SD}=1.08)$ with $P$. mira NBRC $15435^{\mathrm{T}}$ and $31.14 \%(\mathrm{SD}=1.06)$ with $P$. silvatica NBRC $100141^{\mathrm{T}}$ (mean values, all repeated three times). 16S rRNA gene sequence analysis and DNA-DNA relatedness data were sufficient to categorize strains A-T $0875^{\mathrm{T}}$ and A-T $1383^{\mathrm{T}}$ as distinct from previously described Planotetraspora species.

These phenotypic (Table 1) and genotypic data indicated that strains A-T $0875^{\mathrm{T}}$ and $\mathrm{A}-\mathrm{T} 1383^{\mathrm{T}}$ merit classification as representatives of two novel species of the genus Planotetraspora, for which the names Planotetraspora kaengkrachanensis sp. nov. and Planotetraspora phitsanulokensis sp. nov., respectively, are proposed.

\section{Description of Planotetraspora kaengkrachanensis sp. nov.}

Planotetraspora kaengkrachanensis (kaeng.kra.chan.en'sis. N.L. fem. adj. kaengkrachanensis of Kaeng Krachan District, located in Thailand, where the type strain was isolated).

Gram-positive, mesophilic, non-motile actinomycete that forms well-developed and branched substrate hyphae. Colonies are pale yellow on ISP2 medium. Cylindrical sporangia containing four oval- to rod-shaped spores are formed at the ends of short sporangiospores on the aerial mycelium. Spores are non-motile. No soluble pigment is detected in ISP media 2, 3, 4 or 5. Optimal temperature for growth is between 25 and $30{ }^{\circ} \mathrm{C}$. No growth occurs above $37{ }^{\circ} \mathrm{C}$. The maximum $\mathrm{NaCl}$ concentration for growth is $1.5 \%$. Nitrate is not reduced. Utilizes cellobiose, D-lactose, D-mannitol, melibiose and glycerol, but not L-arabinose, Dfructose, D-galactose, raffinose, L-rhamnose, D-ribose, salicin or D-xylose. Acid is produced from D-galactose, D-glucose, D-mannitol and D-mannose, but not from Dlactose, maltose, melibiose, L-rhamnose, raffinose or Dxylose. Peptonization of milk, hydrolysis of starch and gelatin liquefaction are negative. Cell wall contains glutamic acid, alanine and meso- $\mathrm{A}_{2} \mathrm{pm}$. The predominant menaquinones are MK-9 $\left(\mathrm{H}_{4}\right)$ and $\mathrm{MK}-9\left(\mathrm{H}_{2}\right)$. The whole- 


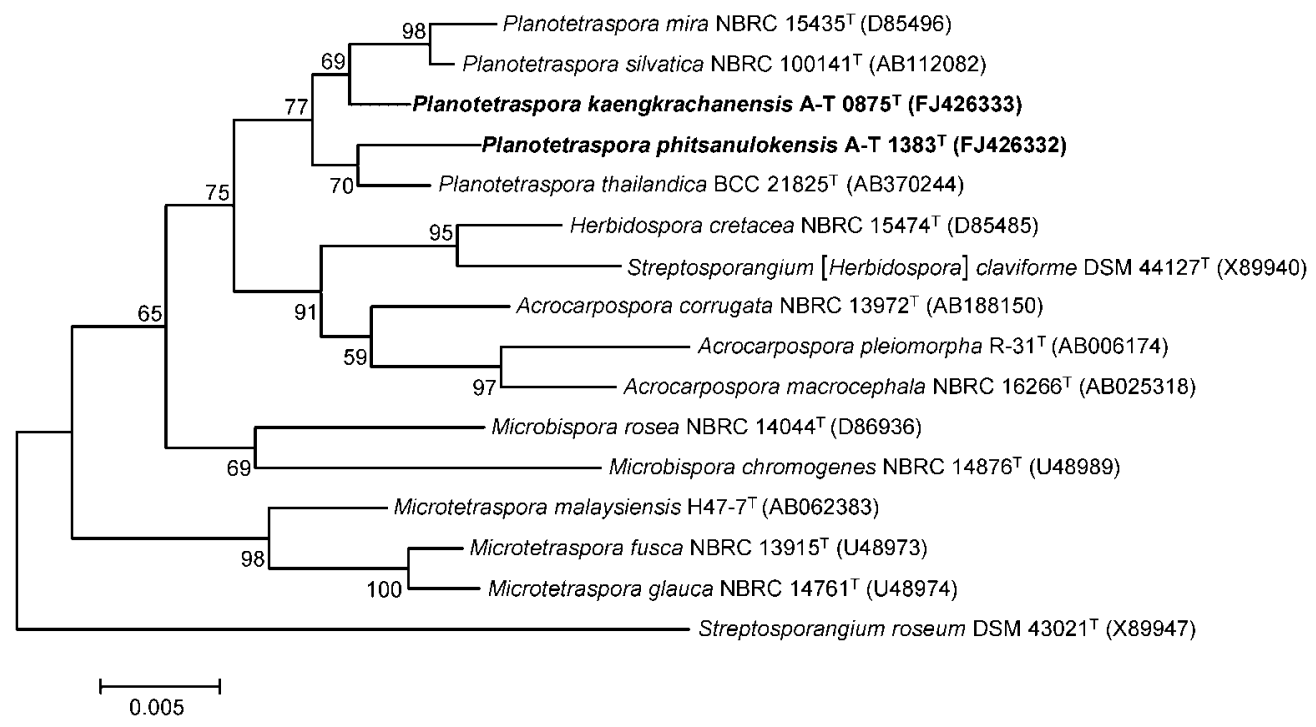

Fig. 1. Phylogenetic relationships based on neighbour-joining analysis (Saitou \& Nei, 1987) of Planotetraspora kaengkrachanensis A-T $0875^{\top}$ and Planotetraspora phitsanulokensis A-T $1383^{\top}$ derived from $16 \mathrm{~S}$ rRNA gene sequences of some members of the family Streptosporangiaceae. Streptosporangium roseum DSM $43021^{\top}$ was used as an outgroup. Numbers at nodes indicate bootstrap percentages derived from 1000 replications (only values greater than $50 \%$ are indicated). Bar, 0.005 substitutions per nucleotide position.

cell sugars are rhamnose, madurose, glucose, galactose and 3-O-methylmannose. The diagnostic phospholipid is phosphatidylethanolamine. The major fatty acids are iso$\mathrm{C}_{16: 0}, 10$-methyl- $\mathrm{C}_{17: 0}$, iso- $\mathrm{C}_{15: 0}$ and $\mathrm{C}_{15: 0}$.

The type strain is A-T $0875^{\mathrm{T}}\left(=\mathrm{BCC} 24832^{\mathrm{T}}=\mathrm{NBRC}\right.$ $104272^{\mathrm{T}}$ ), isolated from soil. The DNA G $+\mathrm{C}$ content of the type strain is $71.0 \mathrm{~mol} \%$.

\section{Description of Planotetraspora phitsanulokensis sp. nov.}

Planotetraspora phitsanulokensis (phit.sa.nu.lok.en'sis. N.L. fem. adj. phitsanulokensis of Phitsanulok Province, located in Thailand, where the type strain was isolated).

Gram-positive, mesophilic, non-motile actinomycete that forms well-developed and branched substrate hyphae. Colonies are colourless on ISP2 medium. Cylindrical sporangia containing four oval- to rod-shaped spores are formed at the ends of short sporangiospores on the aerial mycelium. Spores are non-motile. No soluble pigment is detected in ISP media 2, 3, 4 or 5. Optimal temperature for growth is between 25 and $30^{\circ} \mathrm{C}$. No growth occurs above $37^{\circ} \mathrm{C}$. The maximum $\mathrm{NaCl}$ concentration for growth is less than $1 \%$. Nitrate is not reduced. Utilizes cellobiose, Dgalactose, D-glucose, D-lactose, D-mannitol and glycerol, but not L-arabinose, D-fructose, melibiose, raffinose, Lrhamnose, D-ribose, salicin or D-xylose. Acid is produced from D-glucose, maltose, D-mannitol and D-mannose, but not from D-galactose, D-lactose, melibiose, L-rhamnose, raffinose or D-xylose. Peptonization of milk, hydrolysis of starch and gelatin liquefaction are negative. Cell wall contains glutamic acid, alanine and meso- $\mathrm{A}_{2} \mathrm{pm}$. The predominant menaquinone is MK- $9\left(\mathrm{H}_{4}\right)$. The whole-cell sugars are rhamnose, madurose, glucose, galactose and 3$\mathrm{O}$-methylmannose. The diagnostic phospholipid is phosphatidylethanolamine. The major fatty acids are iso- $\mathrm{C}_{16: 0}$, 10-methyl- $\mathrm{C}_{17: 0}$, iso- $\mathrm{C}_{15: 0}$ and anteiso- $\mathrm{C}_{17: 0}$.

The type strain is A-T $1383^{\mathrm{T}}\left(=\mathrm{BCC} 26045^{\mathrm{T}}=\mathrm{NBRC}\right.$ $104273^{\mathrm{T}}$ ), isolated from soil. The DNA $\mathrm{G}+\mathrm{C}$ content of the type strain is $70.9 \mathrm{~mol} \%$.

\section{Acknowledgements}

We are grateful to Novartis Pharma AG for supporting this project, in particular Esther Schmitt, Rowan Morris, Peter Jager and Frank Petersen. We thank the Biological Resource Center, National Institute of Technology and Evaluation (NITE-NBRC), Chiba, Japan, for supplying cultures of reference strains. This study was supported by the Bioresources Research Network (BRN), Bangkok, Thailand.

\section{References}

Arai, T. (1975). Culture Media for Actinomycetes. Tokyo: The Society for Actinomycetes Japan.

Brosius, J., Dull, T. J., Sleeter, D. D. \& Noller, H. F. (1981). Gene organization and primary structure of a ribosomal RNA operon from Escherichia coli. J Mol Biol 148, 107-127.

Collins, M. D., Pirouz, T., Goodfellow, M. \& Minnikin, D. E. (1977). Distribution of menaquinones in actinomycetes and corynebacteria. J Gen Microbiol 100, 221-230.

Ezaki, T., Hashimoto, Y. \& Yabuuchi, E. (1989). Fluorometric deoxyribonucleic acid-deoxyribonucleic acid hybridization in microdilution wells as an alternative to membrane filter hybridization in 
which radioisotopes are used to determine genetic relatedness among bacterial strains. Int J Syst Bacteriol 39, 224-229.

Felsenstein, J. (1985). Confidence limits on phylogenies: an approach using the bootstrap. Evolution 39, 783-791.

Gordon, R. E., Barnett, D. A., Handerhan, J. E. \& Pang, C. H.-N. (1974). Nocardia coeliaca, Nocardia autotrophica, and the nocardin strain. Int J Syst Bacteriol 24, 54-63.

Hayakawa, M., Sadakata, T., Kajiura, T. \& Nonomura, H. (1991). New methods for the highly selective isolation of Micromonospora and Microbispora from soil. J Ferment Bioeng 72, 320-326.

Itoh, T., Kudo, T., Parenti, F. \& Seino, A. (1989). Amended description of the genus Kineosporia, based on chemotaxonomic and morphological studies. Int J Syst Bacteriol 39, 168-173.

Kämpfer, P. \& Kroppenstedt, R. M. (1996). Numerical analysis of fatty acid patterns of coryneform bacteria and related taxa. Can J Microbiol 42, 989-1005.

Katsura, K., Kawasaki, H., Potacharoen, W., Saono, S., Seki, T., Yamada, Y., Uchimura, T. \& Komagata, K. (2001). Asaia siamensis sp. nov., an acetic acid bacterium in the $\alpha$-Proteobacteria. Int J Syst Evol Microbiol 51, 559-563.

Kawamoto, l., Oka, T. \& Nara, T. (1981). Cell wall composition of Micromonospora olivoasterospora, Micromonospora sagamiensis, and related organisms. J Bacteriol 146, 527-534.

Kawasaki, H., Hoshino, Y., Hirata, A. \& Yamasato, K. (1993). Is intracytoplasmic membrane structure a generic criterion? It does not coincide with phylogenetic interrelationships among photosynthetic purple non-sulfur bacteria. Arch Microbiol 160, 358-362.

Kimura, M. (1980). A simple method for estimating evolutionary rates of base substitutions through comparative studies of nucleotide sequences. J Mol Evol 16, 111-120.

Kroppenstedt, R. M. (1985). Fatty acid and menaquinone analysis of actinomycetes and related organisms. In Chemical Methods in Bacterial Systematics (Society for Applied Bacteriology Technical Series vol. 20), pp. 173-199. Edited by M. Goodfellow \& D. E. Minnikin. New York: Academic Press.

Kudo, T., Itoh, T., Miyadoh, S., Shomura, T. \& Seino, A. (1993). Herbidospora gen. nov., a new genus of the family Streptosporangiaceae Goodfellow et al. 1990. Int J Syst Bacteriol 43, 319-328.

Lechevalier, M. P. \& Lechevalier, H. A. (1970). Chemical composition as a criterion in the classification of aerobic actinomycetes. Int J Syst Bacteriol 20, 435-443.

Lechevalier, M. P., De Bièvre, C. \& Lechevalier, H. A. (1977). Chemotaxonomy of aerobic actinomycetes: phospholipid composition. Biochem Syst Ecol 5, 249-260.

Mikami, H. \& Ishida, Y. (1983). Post-column fluorometric detection of reducing sugar in high-performance liquid chromatography using arginine. Bunseki Kagaku 32, E207-E210.

Minnikin, D. E., O'Donnell, A. G., Goodfellow, M., Alderson, G., Athalye, M., Schaal, A. \& Parlett, J. H. (1984). An integrated procedure for the extraction of bacterial isoprenoid quinones and polar lipids. J Microbiol Methods 2, 233-241.

Nonomura, H. \& Ohara, Y. (1957). Distribution of Actinomycetes in the soil. II. Microbispora, a new genus of the Streptomycetaceae. J Ferment Technol 35, 307-311.
Runmao, H., Guizhen, W. \& Junying, L. (1993). A new genus of actinomycetes, Planotetraspora gen. nov. Int J Syst Bacteriol 43, 468470 .

Saito, H. \& Miura, K. (1963). Preparation of transforming deoxyribonucleic acid by phenol treatment. Biochim Biophys Acta 72, 619-629.

Saitou, N. \& Nei, M. (1987). The neighbor-joining method: a new method for reconstructing phylogenetic trees. Mol Biol Evol 4, 406425 .

Sasser, M. (1990). Identification of bacteria by gas chromatography of cellular fatty acids, MIDI Technical Note 101. Newark, DE: MIDI, Inc.

Schleifer, K. H. \& Kandler, O. (1972). Peptidoglycan types of bacterial cell walls and their taxonomic implications. Bacteriol Rev 36, 407-477.

Shirling, E. B. \& Gottlieb, D. (1966). Methods for characterization of Streptomyces species. Int J Syst Bacteriol 16, 313-340.

Staneck, J. L. \& Roberts, G. D. (1974). Simplified approach to identification of aerobic actinomycetes by thin-layer chromatography. Appl Microbiol 28, 226-231.

Suriyachadkun, C., Chunhametha, S., Thawai, C., Tamura, T., Potacharoen, W., Kirtikara, K. \& Sanglier, J. J. (2009). Planotetraspora thailandica sp. nov., isolated from soil in Thailand. Int J Syst Evol Microbiol 59, 992-997.

Tamaoka, J. \& Komagata, K. (1984). Determination of DNA base composition by reversed-phase high-performance liquid chromatography. FEMS Microbiol Lett 25, 125-128.

Tamura, T. \& Sakane, T. (2004). Planotetraspora silvatica sp. nov. and emended description of the genus Planotetraspora. Int J Syst Evol Microbiol 54, 2053-2056.

Tamura, T., Nakagaito, Y., Nishii, T., Hasegawa, T., Stackebrandt, E. \& Yokota, A. (1994). A new genus of the order Actinomycetales, Couchioplanes gen. nov., with descriptions of Couchioplanes caeruleus (Horan and Brodsky 1986) comb. nov. and Couchioplanes caeruleus subsp. azureus subsp. nov. Int J Syst Bacteriol 44, 193-203.

Tamura, T., Suzuki, S. \& Hatano, K. (2000). Acrocarpospora gen. nov., a new genus of the order Actinomycetales. Int J Syst Evol Microbiol 50, 1163-1171.

Thiemann, J. E., Pagani, H. \& Beretta, G. (1968). A new genus of the Actinomycetales: Microtetraspora gen. nov. J Gen Microbiol 50, 295303.

Uchida, K. \& Aida, K. (1984). An improved method for the glycolate test for simple identification of acyl type of bacterial cell walls. J Gen Appl Microbiol 30, 131-134.

Verlander, C. P. (1992). Detection of horseradish peroxidase by colorimetry. In Nonisotopic DNA Probe Techniques, pp. 185-201. Edited by L. J. Kricka. New York: Academic Press.

Williams, S. T. \& Cross, T. (1971). Actinomycetes. Methods Microbiol 4, 295-334.

Yamada, Y., Katsura, K., Kawasaki, K., Widyastuti, Y., Saono, S., Seki, T., Uchimura, T. \& Komagata, K. (2000). Asaia bogorensis gen. nov., sp. nov., an unusual acetic acid bacterium in the $\alpha$ Proteobacteria. Int J Syst Evol Microbiol 50, 823-829.

Yukphan, P., Potacharoen, W., Tanasupawat, S., Tanticharoen, M. \& Yamada, Y. (2004). Asaia krungthepensis sp. nov., an acetic acid bacterium in the $\alpha$-Proteobacteria. Int J Syst Evol Microbiol 54, 313316. 